\title{
PENTINGNYA KUALITAS PRIBADI KONSELOR DALAM KONSELING UNTUK MEMBANGUN HUBUNGAN ANTAR KONSELOR DAN KONSELI
}

\author{
Amallia Putri ${ }^{1)}$ \\ 1) Prodi Bimbingan Konseling Universitas Negeri Tanjungpura, Pontianak, Indonesia \\ E-mail: Amalliaputri29@gmail.com
}

\begin{abstract}
Abstrak. Sasaran sistem konseling adalah menyediakan kondisi dimana dapat menolong klien agar bisa mengembangkan kekuatan psikologis untuk mengevaluasi perilakunya sekarang dan bisa mendapatkan perilaku yang lebih efektif. Proses belajar berperilaku efektif ini difasilitasi dengan menciptakan lingkungan konseling yang hangat dan aplikasi berbagai prosedur konseling. Untuk mencapai hal tersebut dibutuhkan kualitas hubungan antar pribadi yang baik konselor dan klien. Konseling sebagai sebuah profesi yang digambarkan dengan tampilan konselornya. Konselor profesional merupakan figur yang dapat menampilkan dirinya sebagai teladan. Di antara kompetensi konselor, yang paling penting adalah kualitas pribadi konselor karena konselor sebagai pribadi harus mampu menampilkan jati dirinya secara utuh, tepat, dan berarti, serta membangun hubungan interpersonal yang baik sehingga menjadi motor penggerak keberhasilan layanan. Pribadi konselor merupakan 'instrumen' yang menentukan hasil positif dalam proses konseling, sebab inti dari proses terapeutik dalam konseling yaitu hubungan yang dibangun antara konselor dan konseli. Sehingga kualitas pribadi konselor merupakan hal yang esensial bagi konselor untuk mencapai tujuan dalam proses konseling.
\end{abstract}

Kata kunci: Kualitas Pribadi Konselor; Konseling; Konseli

\section{PENDAHULUAN}

Konselor merupakan pengampu pelayanan ahli bimbingan dan konseling. Bimbingan dan Konseling sebagai sebuah profesi digambarkan dengan tampilnya konselor yang dapat memberikan ketenteraman, kenyaman dan harapan baru bagi klien. Untuk menjadi seorang konselor professional haruslah menampilkan sikap hangat, empati, jujur, menghargai, dan yang paling penting dapat dipercaya (terjaga kerahsiaan konseli) [1]. Ada tiga isu sentral dalam mendiskusikan tentang kualitas pribadi konselor, yaitu : pengetahuan, keterampilan dan kepribadian. Dari ketiga hal tersebut kepribadian merupakan hal yang paling penting meskipun yang lain juga tak kalah pentingnya dan ketiganya merupakan satu kesatuan yang tak dapat dipisahkan [2]. Kualitas pribadi konselor merupakan faktor yang sangat penting dalam konseling. Beberapa hasil penelitian menunjukkan bahwa kualitas pribadi konselor menjadi faktor penentu bagi pencapaian konseling yang efektif. Di antara kompetensi konselor, yang dirasa paling penting adalah kualitas pribadi konselor, karena konselor sebagai pribadi harus mampu menampilkan jati dirinya secara utuh, tepat, dan berarti, serta membangun hubungan antarpribadi yang unik dan harmonis, dinamis, persuasif, dan kreatif, sehingga menjadi motor penggerak keberhasilan layanan bimbingan dan konseling. Dalam hal ini 'alat' yang paling penting untuk dipakai dalam pekerjaan seorang konselor adalah dirinya sendiri sebagai pribadi (our self as a person) [3].
Kepribadian tidak terbentuk semata-mata karena pengalaman, tetapi merupakan suatu integritas dari kemauan dan kemampuan dirinya untuk dapat bersikap dan bertindak sebagai konselor professional. Kepribadian konselor dapat membentuk hubungan antar pribadi yang baik dari konselor dan konseli. Hubungan antar pribadi adalah proses sosial dimana individu-individu yang terlibat didalamnya saling berhubungan dan saling mempengaruhi. Lebih lanjut hubungan antar pribadi adalah suatu hubungan dimana orangorang yang terlibat dalam komunikasi menganggap orang lain sebagai pribadi dan bukan sebagai obyek yang disamakan dengan benda. Jadi dalam hubungan antar pribadi kedudukan dan fungsi antara individu yang satu dengan yang lain adalah setara. Hubungan antar pribadi merupakan kebutuhan dasar sebagai manusia, hal ini dapat dilihat bahwa manusia selalu membutuhkan orang lain dalam kelangsungan hidupnya. Manusia tidak mungkin untuk bisa terlepas dari hubungannya dengan orang lain, termasuk didalamnya proses untuk memenuhi kebutuhannya. Dalam memenuhi kebutuhannya manusia selalu membutuhkan hubungan dengan orang lain. Bahkan yang paling ekstrim pun dalam hal kebermaknaan manusia, manusia baru dapat dikatakan bermakna apabila manusia dalam kapasitas sedang berhubungan dengan orang lain. Untuk mencapai tingkat kepercayaan konseli agar mampu mencapai tujuan konseling yang telah ditetapkan, agar konseli dapat mengekspresikan diri, pengalaman dan perasaannya secara bebas, sehingga pemahaman diri dan lingkungannya akan semakin baik serta timbul keberanian untuk mengambil keputusan secara efektif, maka diperlukan 
kualitas hubungan antar pribadi yang baik dari konselor dalam konseling.

Untuk dapat melaksanakan peranan profesional yang unik dan terciptanya layanan bimbingan dan konseling secara efektif, sebagaimana adanya tuntutan profesi, konselor harus memiliki kualitas pribadi. Keberhasilan konseling lebih tergantung pada kualitas pribadi konselor dibandingkan kecermatan teknik. Mengenai ini, Tyler menyatakan: "...success in counseling depend more upon personal qualities than upon correct use of specified techniques" [4]. Pribadi konselor yang amat penting mendukung efektivitas perannya adalah pribadi yang altuistis (rela berkorban) untuk kepentingan konseli. Kepribadian konselor merupakan titik tumpu yang berfungsi sebagai peyeimbangan antara pengetahuan mengenai dinamika perilaku dan teraputik. Ketika titik tumpu ini kuat, pengetahuan dan keterampilan bekerja secara seimbang dengan kepribadian yang berpengaruh pada perubahan perilaku positif dalam konseling. Namun, ketika titik tumpu ini lemah, yaitu dalam keadaan kepribadian konselor tidak banyak membantu, maka pengetahuan dan keterampilan konselor tidak akan efektif digunakan, atau akan digunakan dalam cara-cara merusak. Kualitas kepribadian konselor, pengetahuan mengenai perilaku, dan keterampilan konseling, masing-masing tidak dapat saling mengantikan. Kepribadian yang baik tetapi dengan kekurangan pengetahuan dan keterampilan ibarat seorang supir yang mengendarai mobil tidak aman. Keyakinan bahwa kepribadian konselor merupakan kunci yang berpengaruh dalam hubungan konseling, akan tetapi kepribadian konselor tidak dapat mengganti kekurangan pengetahuan tentang perilaku dan keterampilan teraputik.

Pembentukan kualitas pribadi tidak sama dengan proses untuk memperoleh pengetahuan tentang perilaku dan keterampilan teraputik. Kualitas kepribadian berkembang dari perpaduan yang terjadi terus-menerus antara genetika, komsitusi, pengaruh lingkungan dan cara-cara unik orang dalam memadukan semua itu sehingga menjadi pribadi yang khas. Pendidikan dan pelatihan lanjut lebih berpengaruh pada pertumbuhan secara kuantitatif dari pada kualitatif. Atau dengan kata lain, pendidikan dan pelatihan tidak banyak dapat membantu orang untuk berkembang menjadi dirinya sendiri. Menjadi konselor yang baik, yaitu konselor yang efektif, perlu mengenal diri sendiri, mengenal konseli, memahami maksud dan tujuan konseling, serta menguasai proses konseling. Membangun hubungan konseling (counseling relationship) sangat penting dan menentukan dalam melakukan konseling. Seorang konselor tidak dapat membangun hubungan konseling jika tidak mengenal diri maupun konseli, tidak memahami maksud dan tujuan konseling serta tidak menguasai proses konseling.

Kualitas pribadi terkait erat dengan perilaku professional [5], Perilaku profesional paling tidak merefleksikan tiga hal, yaitu ; Pertama, perilaku tidak hanya dibatasi pada setting konseling, tetapi situasi apa saja ketika konselor menampilkan perilakunya. Kedua, yang dibicarakan adalah konteks yang seharusnya bukan sesuatu yang secara nyata ditampilkan oleh konselor, Ketiga, siapapun yang mengklain sebagai konselor harus tunduk pada kode etik konselor. Konselor profesional senantiasa terbentuk secara ekologis dengan berpegang teguh pada norma-norma dan nilai-nilai (spiritual, sosial). Perilaku profesional dilandasai oleh keyakinan dan values yang berpengaruh pada integritas kepribadian konselor.

\section{PEMBAHASAN}

Aktivitas bimbingan dan konseling, pada dasarnya, merupakan interaksi timbal-balik, yang di dalamnya terjadi hubungan saling mempengaruhi antara konselor sebagai pihak yang membantu dan klien sebagai pihak yang dibantu. Hanya saja, mengingat konselor diasumsikan sebagai pribadi yang akan membimbing konseli dalam mencapai tujuan tertentu, maka dalam relasi ini sangat dibutuhkan adanya kapasitas tertentu yang harus dimiliki oleh seorang konselor. Kapasitas tertentu inilah yang menentukan kualitas konselor. Konseling yang efektif adalah bergantung pada kualitas hubungan antara klien dengan konselor [6]. Pentingnya kualitas hubungan konselor dengan klien ditunjukkan melalui kemampuan konselor dalam kongruensi (congruence), empati (empathy), perhatian secara positif tanpa syarat (unconditional positive regard), dan menghargai (respect) kepada klien. Hal ini mengakui bahwa akan ada perbedaan model dalam praktek konseling dan secara alami dipengaruhi pada pemilihan model yang dilakukan oleh sebagian konselor. Pada dasarnya bahwa setiap konseli memiliki potensi positif dan kekuatan dalam dimensi waktu kekinian untuk mengembangkan diri. Dengan konsep ini, individu dibawa ke dalam pemahaman kekuatankekuatan diri untuk membangun struktur kepribadian yang mandiri. Implikasi dalam konseling adalah, klien diberi kesempatan untuk membuka diri terhadap pengalamanpengalamannya dan konselor memberikan kesempatan sepenuhnya agar klien mampu mengeksplorasi kekuatan dan potensi dirinya.

Corey [7] menjelaskan bahwa bagian terpenting dalam konseling adalah menjadi konselor yang efektif. Beberapa penelitian pakar konseling mengemukan bahwa keefektifan konselor banyak ditentukan oleh kualitas pribadinya. Kualitas pribadi konselor adalah kriteria yang menyangkut segala aspek kepribadian sangat penting dan menentukan keefektifan konselor jika dibandingkan dengan pendidikan dan latihan yang diperolehnya [8]. Hasil penelitian yang dilakukan Truax \& Charkhuff, Waren, Virginia Satir [8] membuktikan bahwa keefektifan konselor banyak ditentukan oleh kualitas pribadinya. Rogers [8] mengatakan bahwa kepribadian konselor lebih daripada tehnik konseling itu sendiri. Menjadi konselor yang baik, yaitu konselor yang efektif, perlu mengenal diri sendiri, mengenal konseli, memahami maksud dan tujuan konseling, serta menguasai proses konseling. Membangun hubungan konseling (counseling relationship) sangat penting dan menentukan dalam melakukan konseling. Seorang konselor tidak dapat membangun hubungan konseling jika tidak mengenal diri maupun konseli, tidak memahami maksud dan tujuan konseling, serta tidak menguasai proses konseling. 
Secara umum, berangkat dari hasil penelitian tersebut, beberapa karakteristik kepribadian menurut Wilis [8] yang perlu dimiliki seorang konselor adalah sebagai berikut: beriman dan bertakwa; menyenangi manusia; komunikator yang terampil; pendengar yang baik; memiliki ilmu yang luas, terutama tentang wawasan tentang manusia dan sosialbudaya; menjadi narasumber yang kompeten; fleksibel, tenang, dan sabar; menguasai keterampilan atau teknik; memiliki intuisi; memahami etika profesi; respek, jujur, asli, menghargai, dan tidak menilai; empati, memahami, menerima, hangat, dan bersahabat; fasilitator dan motivator; emosi stabil; pikiran jernih, cepat, dan mampu; Objektif, rasioanl, logis, dan konkrit; dan konsisten dan tanggung jawab. Sementara itu, ABKIN [9] merumuskan bahwa salah satu komponen standar kompetensi yang harus dijiwai dan dimiliki oleh konselor adalah mengembangkan pribadi dan profesionalitas secara berkelanjutan, yang di dalamnya meliputi: 1) beriman dan bertakwa kepada Tuhan Yang Maha Esa; 2) menunjukkan integritas dan stabilitas kepribadian yang kuat; 3) memiliki kesadaran diri dan komitmen terhadap etika profesional; 4) mengimplementasikan kolaborasi intern di tempat tugas dan secara eksternal antarprofesi; dan 5) berperan dalam organisasi dan kegiatan profesi bimbingan dan konseling.

Kenyataan menunjukkan bahwa suatu sistem, metode, atau teknik, betatapun ilmiah dan canggihnya, tidak akan berdaya-guna selama tidak dijalankan oleh manusia atau pribadi yang berkualitas. Kualitas pribadi konselor merupakan faktor yang sangat penting dalam konseling. Beberapa hasil penelitian menunjukkan bahwa kualitas pribadi konselor menjadi faktor penentu bagi pencapaian konseling yang efektif, di samping faktor pengetahuan tentang dinamika perilaku dan keterampilan terapeutik atau konseling. Kepribadian merupakan titik tumpu dari dua jenis kemampuan yang lain (pengetahuan dan ketrampilan), namun demikian ketiga aspek memiliki keterkaitan bersifat reciprocal atau dengan kata lain ketiganya harus ada dan saling mempengaruhi. Kepribadian tidak terbentuk semata-mata karena pengalaman, tetapi merupakan suatu integritas dari kemauan dan kemampuan dirinya untuk dapat bersikap dan bertindak sebagai konselor profesional. Figur ini merupakan titik awal dan sebagai landasan sekaligus penyeimbang antara ketrampilan dan kemampuan. Realitas menunjukkan bahwa sikap dan volunteerism (filantropi) konselor memiliki derajat yang tinggi dalam mengangkat klien ke arah pengenalan terhadap realitas. Konselor diharapkan memiliki pribadi yang dapat mencerminkan perilakunya dalam mewujudkan kemampuan dalam hubungan membantu konseli tetapi juga mampu menyadari dunia lingkungannya, mau menyadari masalah sosial politiknya, dan dapat berdaya cipta secara luas dan tidak terbatas dalam pandangan profesionalnya. Maka dari itu dibutuhkan pemahaman yang luas tentang pengembangan pribadi konselor yang terintegrasi, demi tewujudnya lulusan guru pembimbing atau konselor yang profesional dibidangnya.

Kualitas konselor adalah semua kriteria keunggulan termasuk pribadi, pengetahuan, wawasan, keterampilan, dan nilai- nilai yang dimiliki konselor, yang akan menentukan keberhasilan (efektivitas) proses bimbingan dan konseling. Salah satu kualitas adalah kualitas pribadi konselor, yang menyangkut segala aspek kepribadian yang amat penting dan menentukan efektivitas konseling. Rogers [8] menyatakan bahwa ada beberapa kompetensi konselor yang dapat memberikan perubahan langsung terhadap konseli pada saat melakukan proses konseling diantaranya yaitu: 1) Ketulusan, 2) Penerimaan. menghargai konseli sebagai individu yang berharga, 3) Empati yaitu suatu kemampuan untuk menempatkan diri, jiwa, dan perasaan dari konselor ke dalam jiwa, dan perasaan konseli. Beberapa perubahan ini di antaranya konseli akan menjadi: 1) lebih realistis dalam memandang dirinya sendiri, 2) lebih percaya diri dan memiliki kemampuan dalam mengarahkan diri, (3) lebih positif dalam menilai diri sendiri, 4) lebih dewasa, 5) mampu mengatasi stress yang dihadapinya, 6) lebih memiliki struktur kepribadian yang sehat.

Dalam konteks bimbingan dan konseling kualitas pribadi konselor dalam hal sikap dan perilaku sehari-hari akan menjadi modal utama dan pertama dalam menjalankan bimbingan dan konseling yang efektif. Hal itu terjadi karena hanya dengan kualitas pribadi yang tinggilah tujuan konseling akan tercapai, yang lainnya ditentukan oleh teknik yang digunakan. Hal ini menunjukkan bahwa betapa pentingnya kualitas pribadi yang harus dimiliki oleh konselor. Cavanagh [2] merekomendasikan 12 kualitas pribadi seorang konselor, yaitu ; 1) Pemahaman tentang diri sendiri ; karakteristik yang ditunjukkan adalah menyadari kebutuhannya, menyadari perasaannya, menyadari faktor yang membuat kecemasan dalam konseling dan cara yang dilakukan untuk mengurangi kecemasan, dan menyadari akan kelebihan dan kekurangan diri. 2) Kompetensi, upaya mendapatkan kualitas secara fisik, intelektual, emosional, sosial dan kualitas moral yang harus dimiliki oleh konselor. 3) Keadaan psikologis konselor yang baik, konselor yang memiliki kesehatan psikologis yang baik memiliki karakteristik, mencapai kepuasan akan kebutuhannya, proses konseling tidak dipengaruhi oleh pengalaman masa lalu dan pengalaman pribadi di luar proses konseling yang tidak memilliki implikasi penting dalam konseling. 4) Dapat dipercaya, konselor dituntut untuk konsisten dalam ucapan dan perbuatan, memakai ungkapan verbal dan non verbal untuk menyatakan jaminan kerahasiaan, tidak pernah membuat seseorang menyesal telah membuka rahasianya. 5) Kejujuran, konseor bersifat terbuka, otentik dan penuh keihklasan. 6) Memiliki kekuatan untuk mengayomi klien, kemampuan untuk membuat klien merasa aman yang ditunjukkan dalam hal memiliki batasan yang kebekuan suasana, berbagi pengalaman emosional dan memungkinkan klien menjadi peduliberalasan dalam berpikir, dapat mengatakan sesuatu yang sulit dan membuat keputusan yang tidak populer, fleksibel dan menjaga jarak dengan klien (tidak terbawa emosi klien). 7) Kehangatan, merupakan pada dirinya sendiri. 8) Pendengar yang aktif, ditunjukkan dengan sikap dapat komunikasi yang sering dilakukan secara non verbal, dengan tujuan untuk mencairkan berkomunikasi dengan orang di luar kalangannya sendiri, memberikan 
perlakukan kepada klien dengan cara yang dapat memunculkan respons yang berarti, dan berbagi tanggung jawab secara seimbang dengan klien. 9) Kesabaran, sikap sabar ditunjukkan dengan kemampuan konselor untuk bertoleransi pada keadaan yang ambigu, mampu berdampingan secara psikologis dengan klien, tidak merasa boros waktu, dan dapat menunda pertanyaan yang akan disampaikan pada sesi berikutnya. 10) Kepekaan, memiliki sensitivitas terhadap reaksi dirinya sendiri dalam proses konseling, dapat mengajukan pertanyaan yang "mengancam" klien secara arif dan peka terhadap hal-hal yang mudah tersentuh dalam dirinya. 11) Kebebasan, sikap konselor yang mampu membedakan antara manipulasi dan edukasi serta pemahaman perbedaan nilai kebebasan dan menghargai perbedaan. 12) Kesadaran menyeluruh, memiliki pandangan secara menyeluruh dalam hal menyadari dimensi kepribadian dan kompleksitas keterkaitannya, terbuka terhadap teori-teori perilaku.

Beberapa hal yang dapat mempengaruhi konselor berperilaku secara tepat terkait dengan perspektif nilai adalah ; 1) konselor memiliki kualitas pribadi yang positif, 2) kemampuan memahami isu-isu etis dalam konseling, 3) adanya kesadaran kultural dalam konteks multi budaya, 4) konselor dapat membangun kualitas hubungan konselor klien yang efektif, dan 5) konselor mampu memahami prinsip-prinsip keyakinan dan nilai dari perspektif klien [10].

Paparan mengenai kualitas dan karakteristik pribadi konselor yang sangat ideal di atas, tidak dapat dipenuhi oleh seorang konselor secara utuh keseluruhan. Namun, konselor tetap harus berupaya memenuhinya sebanyak mungkin dengan tetap memiliki ciri pribadi sendiri yang khas (unik). Menjadi konselor yang baik, yaitu konselor yang efektif, perlu mengenal diri sendiri, mengenal konseli, memahami maksud dan tujuan konseling, serta menguasai proses konseling. Membangun hubungan konseling (counseling relationship) sangat penting dan menentukan dalam melakukan konseling. Seorang konselor tidak dapat membangun hubungan konseling jika tidak mengenal diri maupun konseli, tidak memahami maksud dan tujuan konseling serta tidak menguasai proses konseling. Sifat dan karakteristik konseling sangat menentukan pribadi konselor, idealnya pribadi konselor dapat mengaktualisasikan diri menjadi pribadi yang bijak dan berorientasi humanistik, peduli terhadap tuntutan profesi. Dengan kualitas pribadi yang baik maka tujuan dari konseling diharapkan dapat tercapai, selain itu didukung oleh kompetensi-kompetensi lainnya seperti kompetensi akademik, sosial dan profesional

\section{KESIMPULAN DAN SARAN}

Proses konseling yang merupakan sentral layanan konseling dilakukan sesuai dengan kaidah profesi dan kode etik yang ditetapkan. Konselor merupakan sebuah profesi, Tuntutan secara profesi, konselor harus memiliki kualitas pribadi yang memadai untuk menunjukkan profesionalisme perilaku dan aktivitasnya. Konselor yang memiliki pribadi mantap, akan sangat menyadari profesinya, yang harus ditunjang dengan kompetensi-kompetensi pribadi, akademik, sosial dan profesional. Efektivitas konseling sangat ditentukan oleh kualitas pribadi konselor. Konseling yang efektif bergantung pada kualitas hubungan antara klien dengan konselor. Pentingnya kualitas hubungan konselor dengan klien ditunjukkan melalui kemampuan konselor dalam kongruensi (congruence), empati (empathy), perhatian secara positif tanpa syarat (unconditional positive regard), dan menghargai (respect) kepada klien. Kepribadian merupakan titik tumpu dari duajenis kemampuan yang lain (pengetahuan dan ketrampilan), namun demikian ketiga aspek memiliki keterkaitan bersifat reciprocal atau dengan kata lain ketiganya harus ada dan saling mempengaruhi.

Kepribadian tidak terbentuk semata-mata karena pengalaman, tetapi merupakan suatu integritas dari kemauan dan kemampuan dirinya untuk dapat bersikap dan bertindak sebagai konselor profesional. Karena kepribadian konselor ini dirasakan sangat penting adanya dalam proses konseling yang dilakukan konselor dan konseli, maka disarankan agar konselor terus mengasah kemampuan diri untuk menyadari bahwa dirinya merupakan seorang helper, dengan menyadari fungsi diri maka konselor akan dapat memahami keadaan konseli dengan lebih baik sehingga terbentuklah kepribadian yang mantap. Serta para calon konselor/ konselor diharapkan meningkatkan kualitas diri melalui jalur formal untuk mencapai standar kompetensi tertentu, sedangkan usaha magang dipakai sebagai model untuk menjembatani antara teori dengan praktek, sejauh mana kemampuan konselor/ calon konselor dalam mengimplementasikan studi ilmiahnya terhadap pengalaman-pengalaman di lapangan. Jalur formal menjadi salah satu media bagi calon konselor untuk mengembangkan kemampuan keterampilan dan pengetahuan tentang teori, konsep dan kerangka seorang konselor.

\section{DAFTAR PUSTAKA}

[1] Sanyata, Sigit. 2006 . Perspektif Nilai Dalam Konseling : Membangun Interaksi Efektif antara Konselor - Klien. Jurnal: Diterbitkan pada Jurnal Paradigma, No. 02 Th. I, Juli 2006 ISSN 1907-297X Universitas Negeri Yogyakarta

[2] Cavanagh, ME. 1982. The Counseling Experience: A Theoretical and Practical Approach. Monterey. California : Brooks/Cole Publishing Company.

[3] Corey, G. 1986. Konseling dan Psikoterapi. Jakarta : Alfabeta

[4] Tyler, L. E. 1969. The Work Of The Counselor. New York. Appleton Century Crofts, Inc.

[5] Okun, Barbara F,. 2002. Effective Helping : Interviewing and Counseling Techniques. Canada. Wadsworth Group.

[6] Geldard, D, dan Geldard, K,. 2001. Basic Personal Counselling Training Manual forCounsellors. Australia : Peardon Education, Inc.

[7] Corey, Gerald. 2005. Theory and Practice of Counseling and Psychotherapy. Seventh Edition. Belmont : Brooks/Cole Thompson Learning.

[8] Willis, Sofyan S. 2007. Konseling Individual Teori dan Praktek. Bandung: Alfabeta.

[9] ABKIN. 2007. Penataan Pendidikan Profesional Konselor dan Layanan Bimbingan dan Konseling dalam Jalur Pendidikan Formal. Jakarta: Departemen Pendidikan Nasional.

[10] Remley, TP, Jr. 2005. Ethical, Legal and Professional Issues in Counseling. New Jersey. Pearson Education, Inc. 